\title{
The Farm Sector in the 1980s: Sudden Collapse or Steady
} Downturn?

\author{
Michael T. Belongia
}

Whas become popular to discuss the recent history of farm income and debt in the context of a 1973-80 boom period and a post-1980 collapse in the farm sector's performance. 'This view suggests that the per. formance of the farm sector since 1980 represents a sharp break with historical experience.

This article reviews the evidence used by some analysts to argue that the farm sector's downturn is a recent phenomenon. It then analyzes alternative indicators more representative of the farm sector's economic health and concludes that the 1980 s are little more than the continuation of a long-established downward trend.

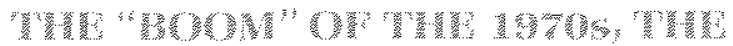 " "}

The performance of U.S. agriculture in the $1970 \mathrm{~s}$ generally is characterized as a boom period on the basis of two indicators: export volume and asset values. As the indexes ploted in chart 1 show, exports and asset values rose rapidly through 1980; both series, however, have fallen precipitoasly since then. The 35 percent increase in U.S. fam export volume between 1973 and 1980 was the combined result of many coincident changes: production shorfalls in other grain producing countries, the fall in the

Michael T. Belongia is a senior economist at the Federal Reserve Bank of St. Louis. Paul Crosby provided research assistance. dollar's real exchange value following the switch to floating exchange rates), rapid growth in real foreign incomes and strong incentives from domestic commodity programs for U.S. farmers to expand output. Over the same period, a rising U.S. inflation mate, tax advantages associated with ownership of farmland and the incentives of commodity programs to expand production increased the demand for farm assets, primarily land. The resull was a 46 percent increase in the real value of farm assets. Thus, the sharp increases in these two indicators presumably signalled that the markets for U.S. farm products were growing and that owners of assets employed in farm production were becoming wealthier.

Interpreting these indicators broadly as measures of economic well-being supports the current notion that the farm sector's collapse began in 1981. Moreover, their parallel declines since then have been viewed as more than coincidence. With real farm exports falling 46 percent and real asset values falling 35 pereent between 1980 and 1985 , a causal chain seems clear: the loss of export markets abroad causes a decline in farm incomes, which, in turn, causes declines in asset values and defaults on farm debt. Given this view of when and why the farm sector's problems originated, the apparent solution to the problem is to stimulate exports. This intent is expressed clearly in the $1985 \mathrm{Farm}$ Bill and the discretionary implementation of its provisions by the Secretary of Agriculture. With greater foreign sales, presumably, fam income, prices and asset values all will rise. 
Chart 1

Real Farm Assets and Real Farm Exports

$1970=100$

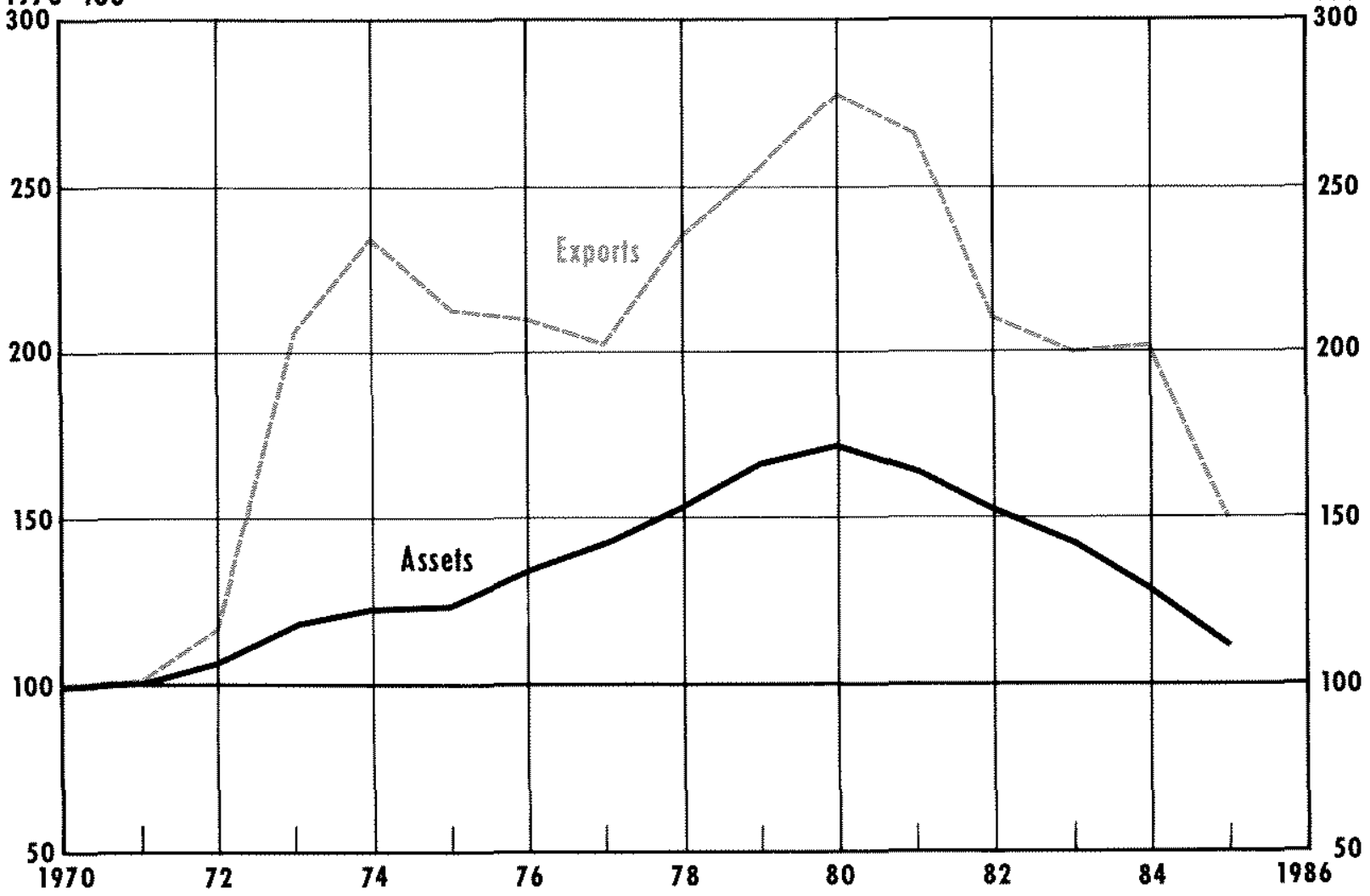

$1970=100$

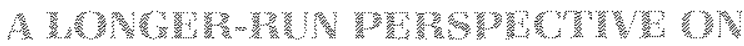

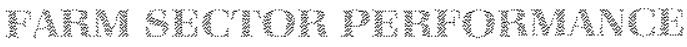

There are at least two pitfalls to using export volume and asset values as primary indicators of the farm sector's economic health. First, selling larger quantities of output to foreign buyers says nothing about the profitability of farming. Export volume is solely a measure of quantity; it may bear little predictable relationship to the net returns earned by the labor and capital employed in farming. The export measure provides no information about the costs of producing farm products relative to prices received by farmers.

Second, the appreciation of farmland prices during the 1970 s masked the incipient severe financial problem now facing farmers. Farmers were earning a relatively low return from farming itself; their chief gains accrued from the capital appreciation of farmland resulting from undes-anticipated inflation. Farmers who borrowed against their higher-valued land were borrowing against gains in wealth that were not related to the income associated with farming. This financial strategy could be pursued only so long as asset values continued to rise fast enough to support the higher debt load they acquired.

\section{A r w

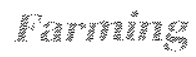

A considerably different picture of the farm sector's performance can be discerned from examining patterns in the relevant price, productivity and income data.

This alternative longer'run history of the farm sector begins with the relationships shown in figure 1 and chart 2. Figure 1 depicts total product (Panel (a)) and marginal product (Banel $(b)$ curves and illustrates a fundamental law of economics, the law of diminishing 


\section{Figure 1}

\section{Relationships Between Quantity of Output Produced and Quantity of an Input Employed}

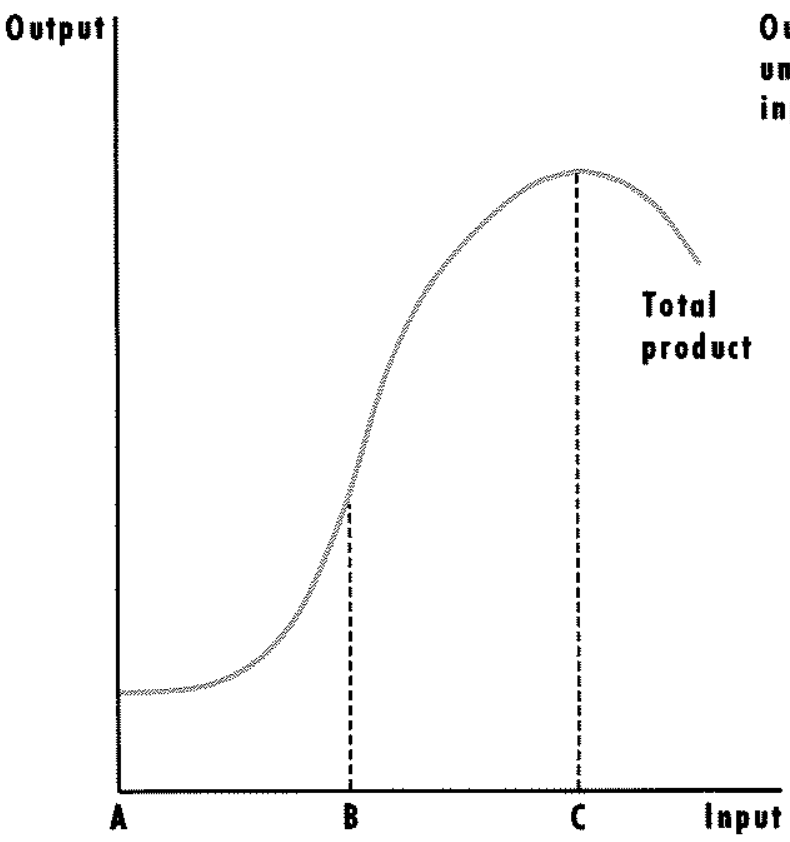

Panel (a)

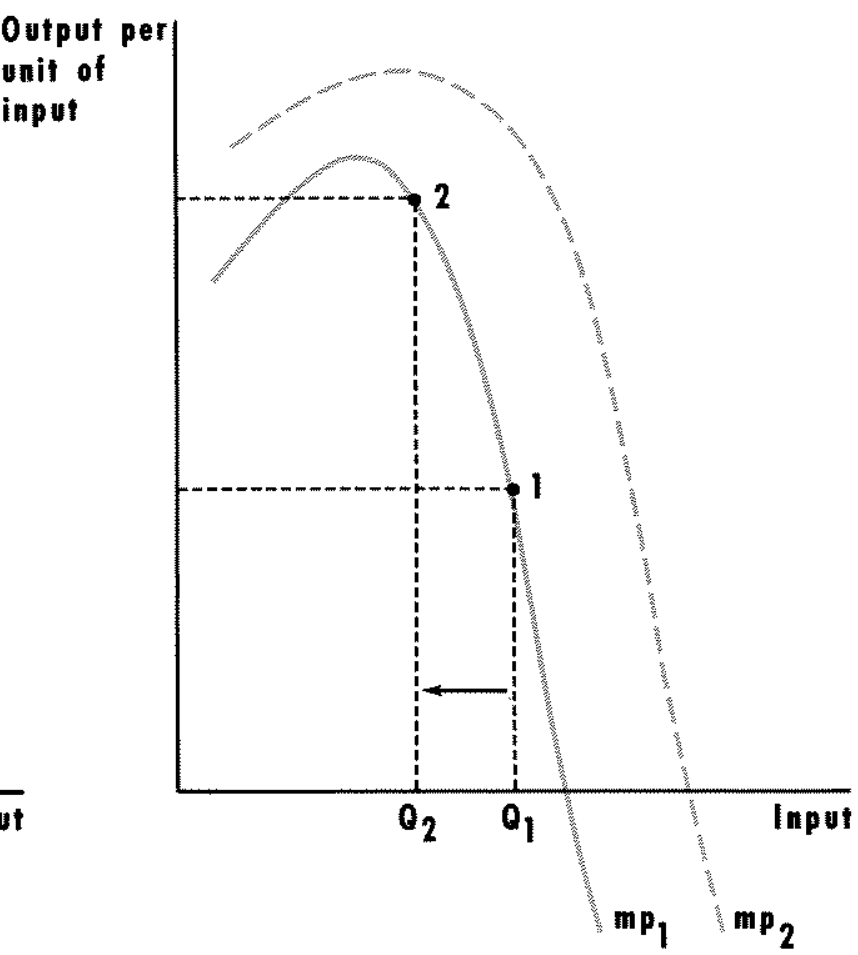

Panel (b) returns. Total product is the total amount of output that can be produced from any particalar quantity of inputs land, labor, capital and other resources) used in production. Marginal product represents the change in total product that results from a change in the quantity of one input, holding the quantities of other inputs constant. The law of diminishing returns says that, at some point, the additional output gained from an extra unit of one input (marginal product) will begin to decline. Moreover, beyond some point, adding more units of an mput reduces total product; the marginal product of this input is now negative. These relationships are discussed extensively in many microeconomics textbooks; thus, it is sufficient for current purposes simply to assert that, when more of any one input is added, while holding the quantities of other inputs constant, total output rises fist at an increasing rate (between points $A$ and $B$, then rises at a decreasing rate (between points $B$ and $C$ ) and, finally, declines to the right of point $\mathrm{C}$.'

'See, for example, Stigler (1947), pp. 117-24; Hirshteifer (1976), pp. $344-45$
Looking at Panel (b) of the figure, it is clear that we can observe greater productivity in the production of some commodity as a result of two very different causes. On the one hand, it is possible to move from point (1) to point (2) on curve $M P_{1}$ : a reduction in the quantity of a specific input employed is associated with a movement back along the MP cuve. "The marginal product of the specific input remaining in the industry will be higher than before, although total product is lower. A second altemative is that some technological improvement shifts the entire MP curve to something like MP, thus, the marginal product for any quantity of input is greater under the new tech nology $\left(\mathrm{MP}_{2}\right)$ than under the old $\left(\mathrm{MP} \mathrm{P}_{1}\right)$.

There is, of course, a substantial difference between the two cases. The first case results from centain inputs leaving the industry; the second case results in additional inputs entering the industry." The data for

The MP curve, multiplied by the price of the fnal good produced by this and other inputs, is the demand curve for the input. An outward shift in the MP (or VMP) curve, therefore, reflects an increase in the demand for that input. 
Chart 2

\section{Indexes of Farm Labor and Farm Labor Productivity}

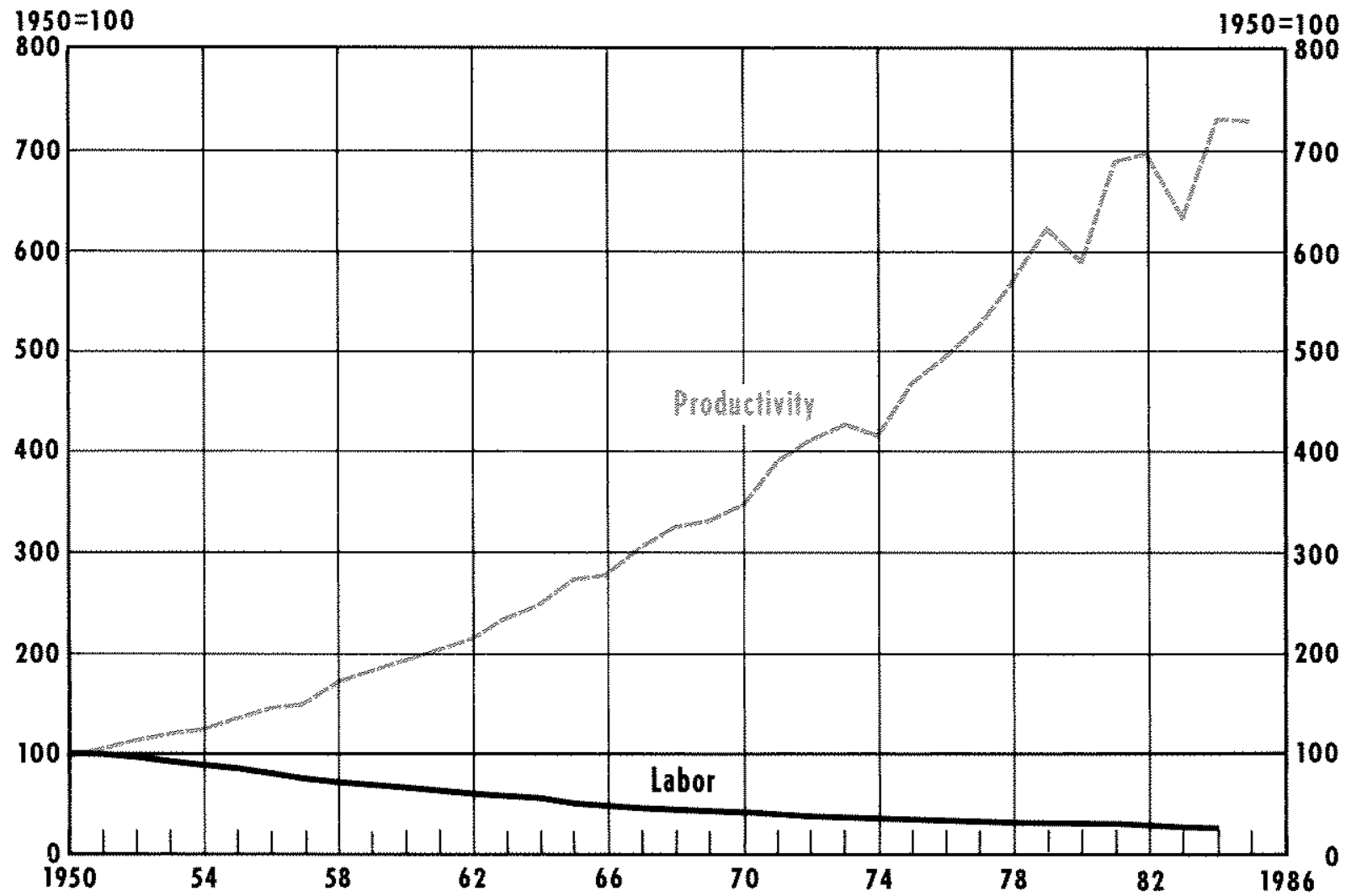

the farm sector, shown in chart 2, indicate that agriculture's productivity gains have been associated with reduced numbers of farmers. Starting from common index bases of 100 in 1950, the chart shows that output per farm worker has increased over 600 percent while the number of farm workers has dechined about 70 percent. The data appear to be consistent with an upward movement along a curve such as $M P$, rather than an outward shift in factor productivity such as $\mathrm{MP}_{2}$. The coincident observation of both greater productivity and fewer farmers suggests that agriculture is now a declining industry and, moreover, has been so for several decades.

All things equal, more output per unit of input helps famers as it would allow them to sell more product from the same amount of effort devoted to faming. But, all things are not equal. A change in prices of farm products also affects the well being of farmers. Total revenue (TR) received by farmers is defined as price $(P)$ times quantity sold ( $O$ ). We already have seen that productivity and total output have increased signifcantly in farming. The dashed green line plotted in chart 3 shows, however, that greater productivity in conjunction with other factors, such as slow growth in food demand) has resulted in lower prices of farm products relative to prices of nonfarm products. With output rising and prices falling, what will happen to the well-being of famers?

The result has to do with the elasticity of demand for farm products. For purposes of calculating the effect of changing prices on farm revenues, most studies estimate the price elasticity of food demand to be near $-0.2 .^{3}$ If we assume, for ease of graphical illustra-

\footnotetext{
See, for example. King (1979), for a review of food demand siludies. The income elasticity typically is estimated to be near 0.2 , which suggests that food demand will increase slowly, relative to general economic growth, and instead will depend more on the growth of population than other factors.
} 


\section{Chart 3}

\section{Real Net Farm Income and Relative Farm Prices}

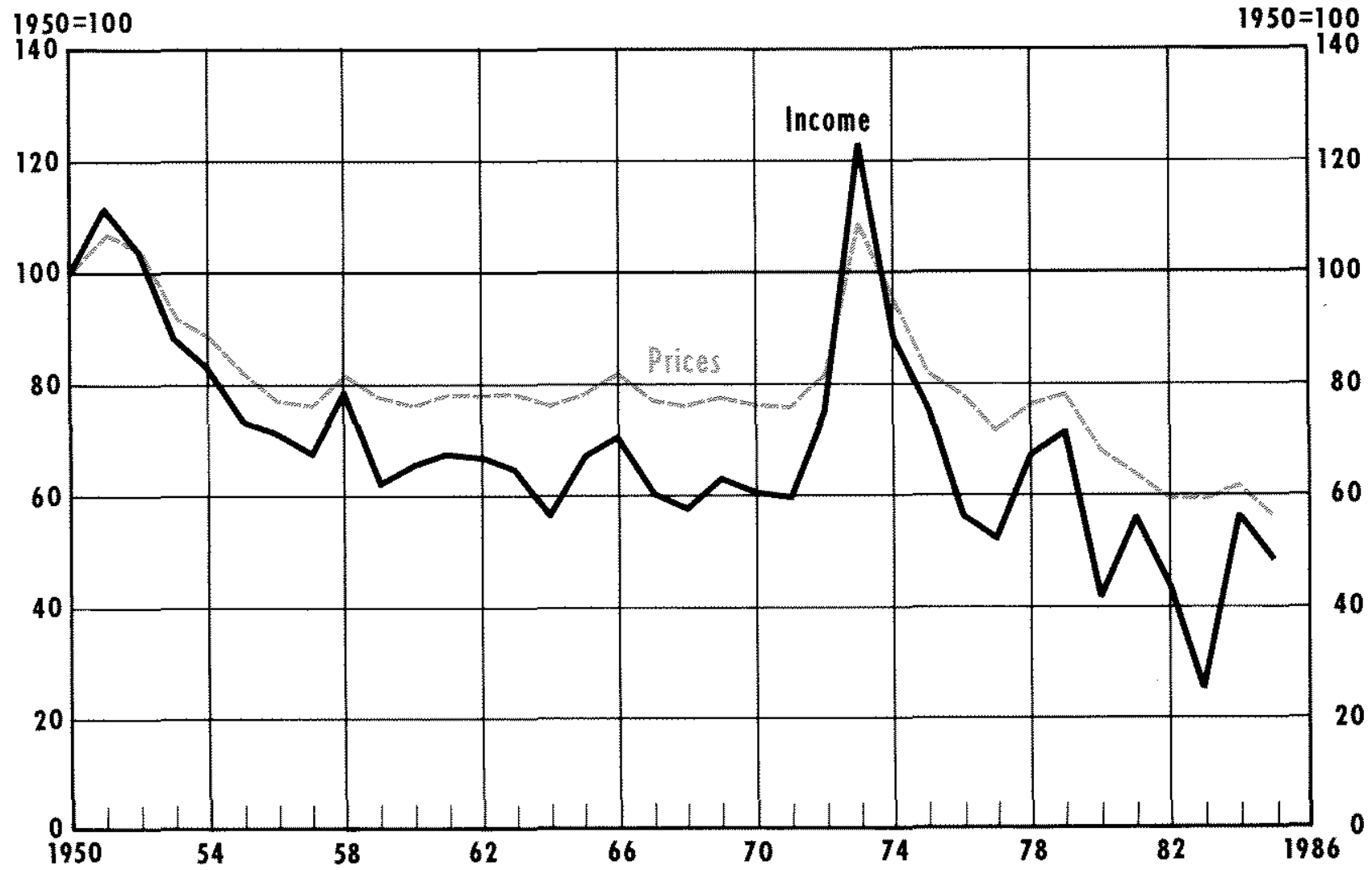

tion (figure 2), that the demand curve for farm products is linear, it can be demonstrated that the marginal revenue curve for sales of farm products also will be linear and intercept the horizontal axis at exactly onehalf the distance between the origin and the point where the demand curve touches the horizontal axis." It also is well known that a price elasticity of demand equal to -0.2 is on the lower portion of the demand curve and is associated with negative marginal revenue. That is, a given percentage change in output will cause a larger percentage change in price in the opposite direction; consequently, total revenue $(\mathrm{P} \times \mathrm{O})$ will fall with greater farm productivity. Unless the costs of farm production are falling faster than the prices of farm products land the relative price line in chart 3 suggests the oppositel, the end result will be lower real farm income.

For proofs of this proposition, see Stigler, pp. 55-57 or King, pp 840-41.
And, in fact, the solid black line in chart 3 shows that real farm income has been on a steady downward trend for many years. Real net farm income in 1985 was less than one-half of its value in 1950 . Over the last 10 years, real net farm income has averaged $\$ 29.3$ billion (in 1982 dollars), about 40 percent less than its $\$ 47.6$ billion average value in the 1950 s. Given the prior history of farm income, the "boom" of the 1970s appear's to be best described as unusual.

Some might argue that the plot in chart 3 is misleading because income is not measured on a per capita basis. Because numbers of farmers and farms have been declining so rapidly, per capita income actually has risen in recent years. Clearly, it is not sensible to interpret the rising per capita farm income measure as

5There are a number of probtems with farm population series that lead to questions about what per capita measures of farm income mean. 
implying improvements in the welfare of farmers vis-avis the rest of the economy. If so, we ought to observe increases in the number of farmers rather than what we actually see. Again, the point goes back to the marginal product curves in figure 1 . The fact that farm productivity is rising while resources are leaving the industry suggests an upward movement along the MP, curve in contrast to, say, the computer industry, which is making great gains in productivity and attracting new resources to the industry. In fact, the returns to farming still must be below the returns to other occupations - farmers are continuing to leave farming for nonfarm activities."

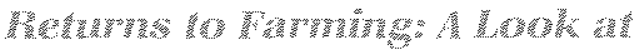

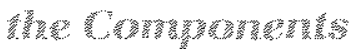

In light of the foregoing analysis of long-term declining returns to farming, why were the 1970 s a boom period? Chart 4 shows that the boom period was one of exceptional capital gains, not exceptional earnings from farm production. By dividing total returns to farming into income and capital gains components, the chart verifies the earlier discussion of income being generally low and trending downward. During agriculture's boom of the 1970s, however, capital gains were positive and, with the exception of 1974, at levels substantially above the percentage return represented by income. For example, in 1972, when farm income produced only a 2.9 percent return on equity, capital gains generated a 10.6 percent return on equity. By the late 1970s, the share of total returns produced by capital gains became even larger. Income's share of the refurn on equity was 1.5 percent or less in each year between $1976-79$, while capital gains, over the same four years, showed an average return of about 9.5 percent. Chart 5 reinforces the point by noting that, with the exception of $1972-74$, capital gains have represented nearly all of the returns to equity in farming.

The problem with using changes in farm asset values as a benchmark of farm sector performance becomes clearer when comparing the appreciation of farm assets with changes in other asset values. During

This observation is not new. T. W. Schultz suggested in the 1950 s that government heip expedite the flow of farmers to nonfarm work with a "reverse-homesteading" plan. Recognizing atready that increasing farm productivity would make farming unprofitable for many current farmers, but that their transition to nonfarm work might be impeded by lack of skills, the notion was to give famers a lump-sum payment that would allow them to establish an urban homestead and enter nonfarm employment. See D. G. Johnson (1958), p. 131.

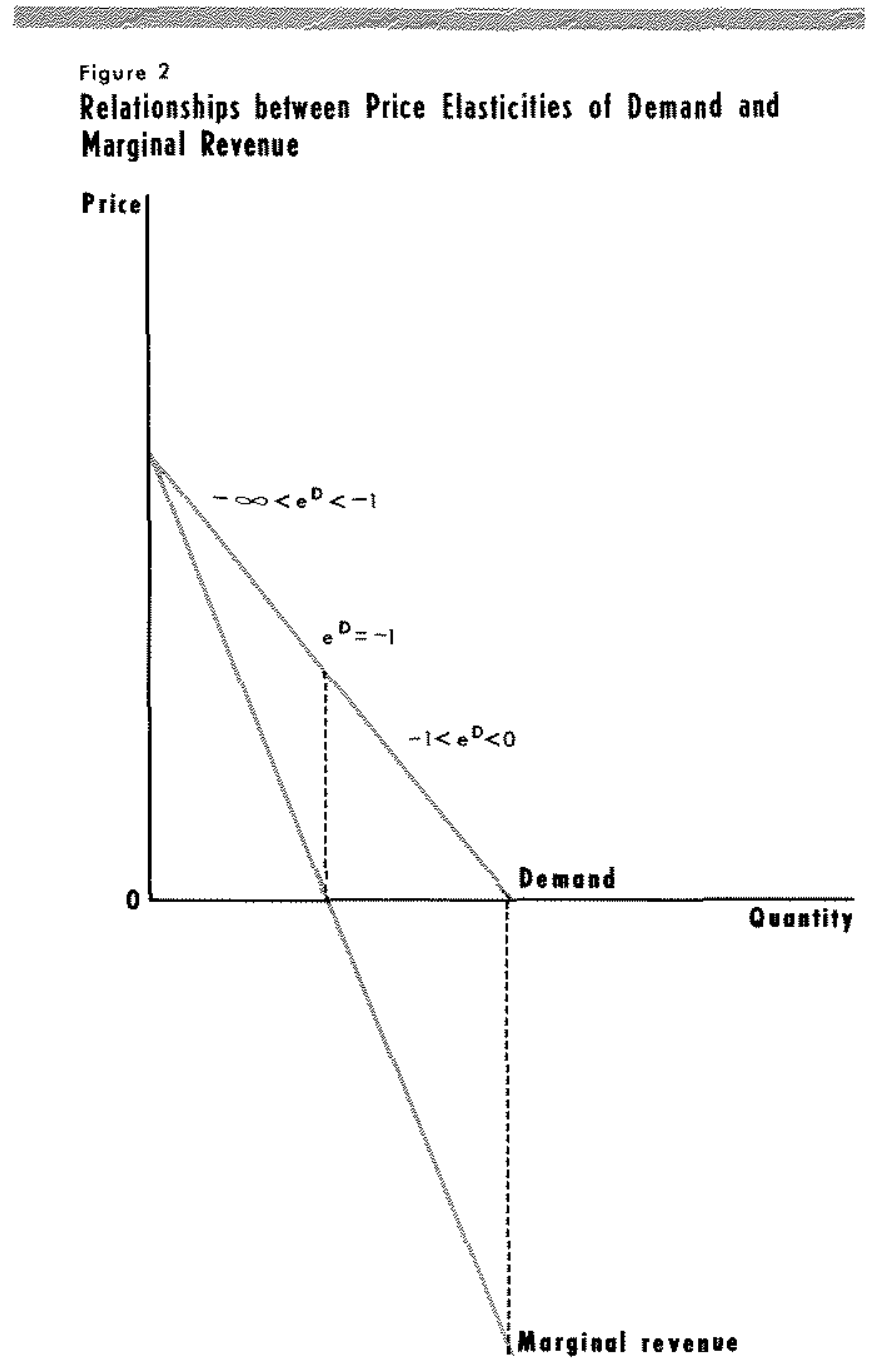

1.7-2.

the 1973-80 "boom," while the value of farm assets rose 152 percent, the median price of a single-family home rose 115 percent, the price of gold increased 526 percent and the value of stockholders' equity in all manufacturing corporations rose 79 percent. Thus, while farm asset values increased during the 1970s, both absolutely and relative to the prices of some assets, they declined relative to prices of other assets.

The point is simply that, in an environment of high actual inflation and accelerating inflationary expectations, individuals will make changes in their portfolio holdings to hedge against the capital losses associated with unexpected changes in inflation and interest rates. Increases in farm asset values, as well as the values of a whole variety of comparable assets with varying sets of characteristics (liquidity, use in consumption or production, etc., reflected these portfolio adjustments. The data on prices of farm products 
Chart 4

\section{Return to Equity from Income and Real Capital Gains}

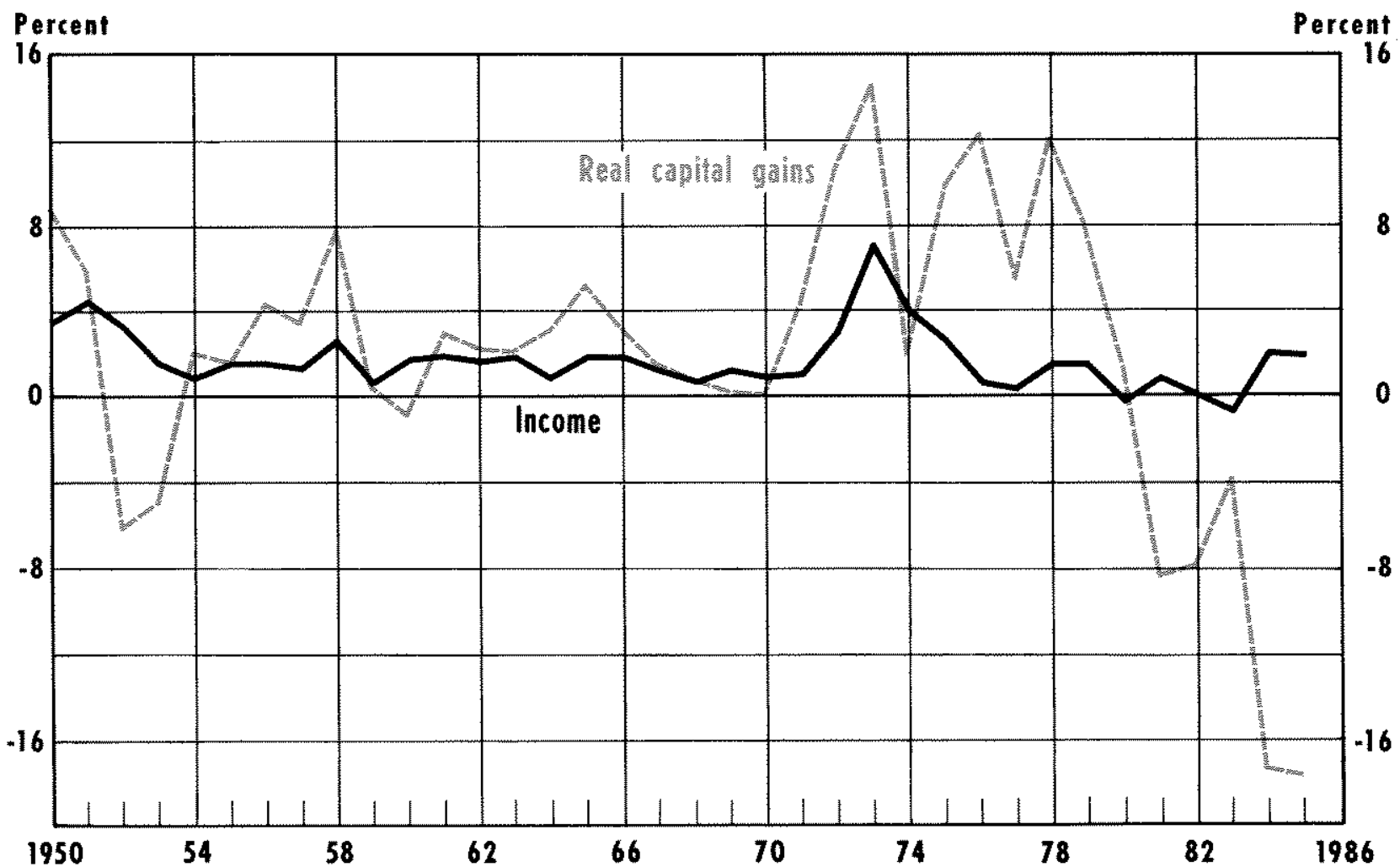

or farm income, however, suggest that the rising fam asset values were not the result of higher profits from farming per se.

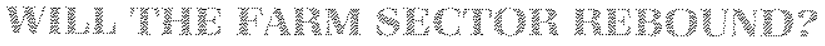

In contrast to the persistent negative trends depicted in the previous section, some analysts have argued that a lower value for the dollar's exchange rate would stimulate fam exports, raise farm income and reverse the decline in farm asset values. As mentioned earlier, this view is embodied in the phitosophy of the 1985 rarm Bill and is espoused by some fam economists. Although few believe that exports will rebound to levels of 1980 , many argue that there are significant opportunities to recoup a large share of the $\$ 18$ billion in export sales lost in the last five years.

At least two pieces of evidence disagnee with the prospect of significantly larger export sales. The first is the sharp gain in farm production in foreign nations in recent years. As table 1 shows, increases in U.S, production of wheat and cotton account for less than 10 percent of the increase in world production between 1980 and 1985; increases in U.S. soybean production are about one-fifth of the total gain. Only in corn production has the rest of the world lagged behind the United States.

These data support the general conclusion that for a variety of reasons, foreign producers have expanded farm output considerably during the 1980 s. $^{5}$ With relatively slow growth in world food demand and rapid increases in the productive capacity of nations that formerly imported U.S. food commodities, it is difficult to see where there is potential to expand U.S. farm exports.

7Reasons often given are the high world price floor set by U.S. commodity programs during the late 1970 s, the view that the U.S. was an "unreliable" supplier after the 1980 embargo on grain sales to the Soviet Union and domestic policy decisions in foreign countries regarding food self-sufficiency. 
Chart 5

Return to Equity and Share Represented by Real Capital Gains

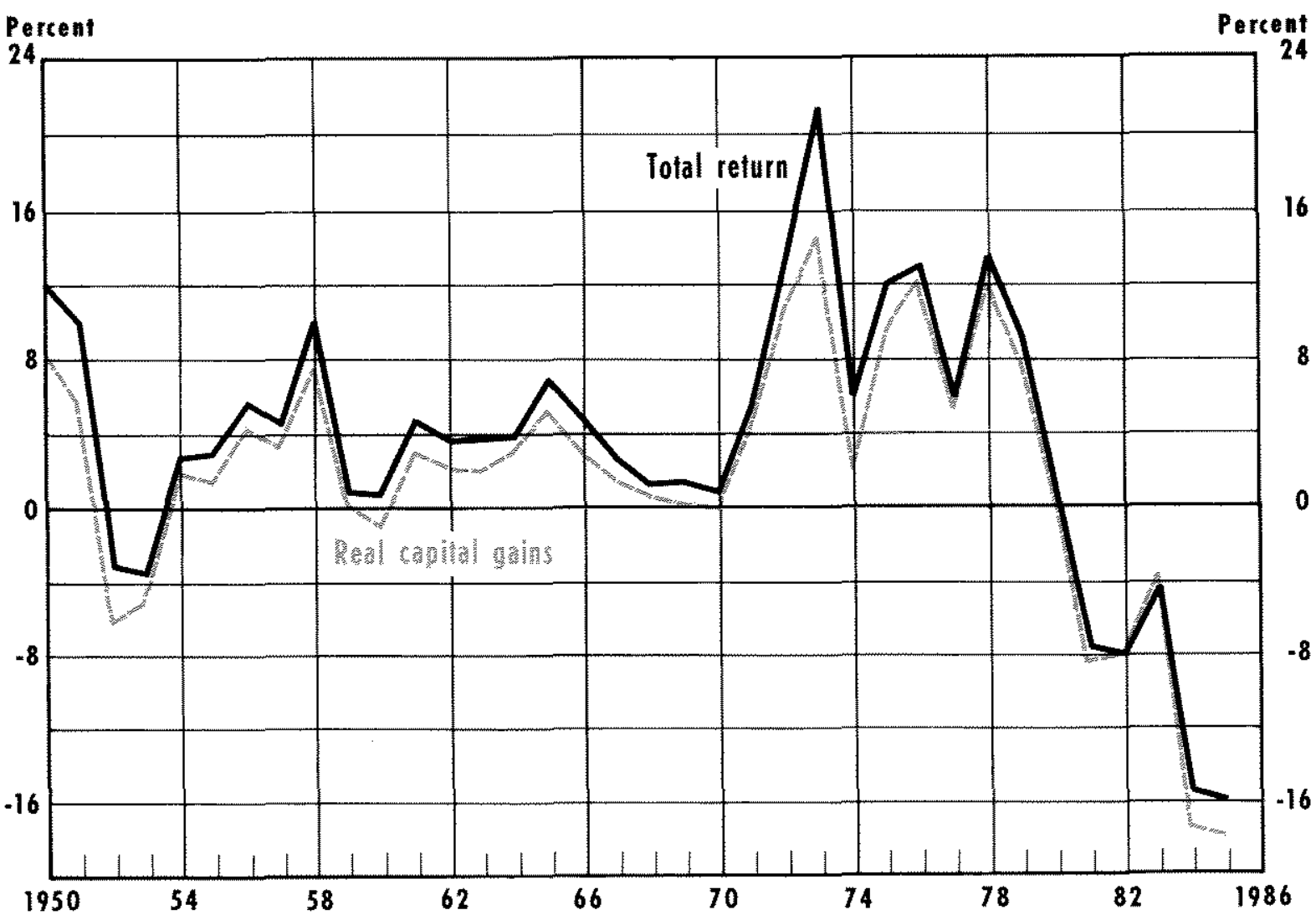

Table 1

Changes in Total and U.S. Production of Major Crops, 1980-85

\begin{tabular}{|c|c|c|c|c|}
\hline Crop & $\begin{array}{l}\text { Increases in } \\
\text { US } \text { production } \\
\text { (million tons) }\end{array}$ & of change & $\begin{array}{l}\text { Increases in } \\
\text { world production } \\
\text { (million tons) }\end{array}$ & $\begin{array}{l}\text { Rate } \\
\text { of change }\end{array}$ \\
\hline Wheat & 60 & $93 \%$ & 716 & $16.2 \%$ \\
\hline Soybeans & 19 & 38 & 9.5 & 117 \\
\hline Cotton & 0.4 & 167 & 43 & 30.0 \\
\hline Corn & 257 & 152 & 430 & 10,6 \\
\hline
\end{tabular}

SOURCE, Agricultural Statistics, 1985 , USDAGPO (1986) and 1983 , USDAGPO (1983) 
Chant 6

Two Measures of Excess Capacity in Farming (Seven-year moving averages)

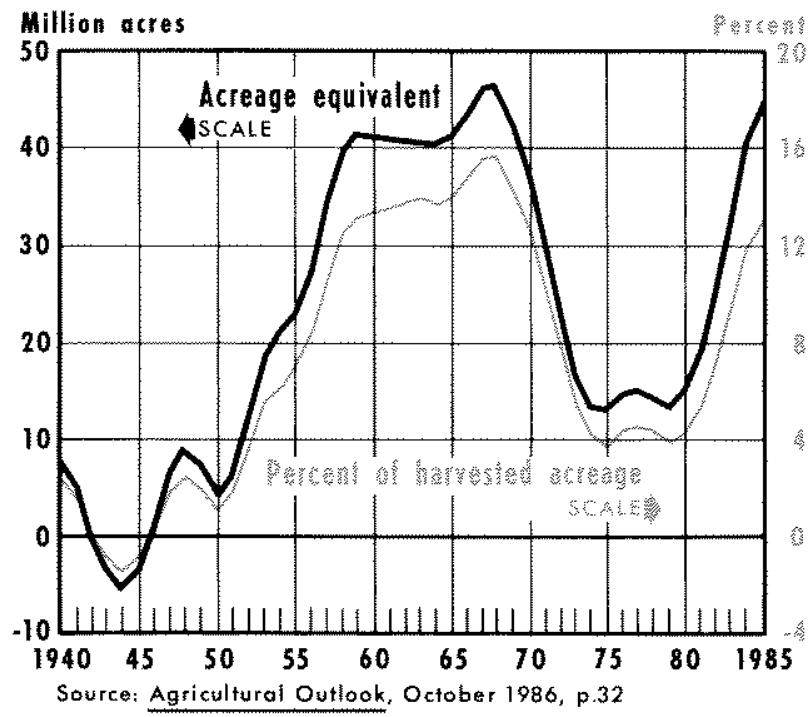

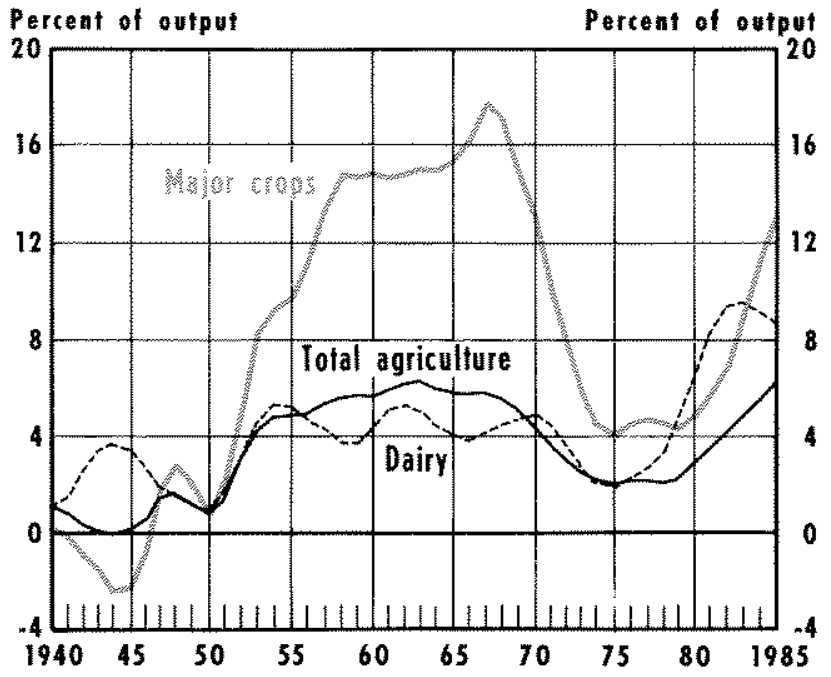

A second reason to doubt any reversal in the longrun decline in the size of the farm sector is the persistence of excess farm capacity in the United States, even during the export boom years. Chart 6 , which depicts the excess capacity of the U.S. farm sector as a percent of total farm output, shows that longrum excess cam pacity now is near the post-1940 high of six percent that prevailed during most of the 1960 s. Excess capacity for major crops, now at 13 percent, has risen to levels that existed prior to the export expansion of the 1970 s. With another significant expott expansion unlikely, however, it is difficult to see how this excess capacity will be reduced except by a reduction in the resources engaged in farming.

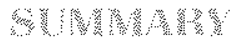

A short and selective view of history suggests that the farm economy was reasonably healthy prior to the collapse that began in 1981. This assessment is based on the substantial gains in export volume and asset values that wete realized during the 1970 s. Neither of these measures, however, has much to say about the inherent past or future profitabilify of farming.

${ }^{8}$ Excess capacity is defined as the difference between potential supply and commercial demand at prevailing prices. Potential supply is actual production plus possible production from diverted acres. See Droskin, p. 31.
A longer-run view of the relevant data of the $1970 \mathrm{~s}$ indicates that farming fundamentals - primarily rela tive prices and real income - have been declining for many years. In contrast, asset values have fluctuated erratically in response to accelerating inflation, tax incentives and other factors largely unelated to the returns from producing and selling farm output. While it is the that farmland price appreciation made many farmers wealthy prior to 1981 , this wealth increase occurred despite the decline in the profitability of farming itself.

\section{Whans?}

Dvoskin, Dan. "Excess Capacify and Resource Allocation in Agriculture, 1940-1985," Agricultural Outlook, USDA - Economic Research Service (October 1986), pp. 31-33.

Hirshleifer, Jack. Price Theory and Applications. Englewood Clffs, N.J.: Prentice-Hall, Inc. (1976).

Johnson, D. Gale. "Government and Agriculture: Is Agriculture a Special Case?" Joumal or Law and Economics (October 1958), pp. 122-36.

King, Richard A. "Choices and Consequences," American Journal of Agricultural Economics (December 1979), pp. 839 48.

Stigler, George J. The Theory of Price. New York: The Macmilan Company (1947) 